Mr. Craig, a recognized municipal leader in the planned unit movement, has been instrumental in providing the City of Pittsburgh with the Planned Development District. His article, which draws upon the Pittsburgh experience, is addressed to the municipal official's basic problem: How to permit planned developments without waiting until the state adopts a more amenable enabling statute? The author also discusses a range of problems, from the policy decisions to the mechanical steps needed to implement policy, that constitute impediments to community action.

\title{
PLANNED UNIT DEVELOPMENT AS SEEN FROM CITY HALL
}

\section{Datid W. Cratg $\dagger$}

Despite advocacy by an impressive array of architects, large scale builders, law professors, ${ }^{1}$ and professional planners, the concept of planned unit development has failed to gain acceptance among many municipal officials. An unduly skeptical attitude toward the techniques of modern land use control has been particularly marked in suburban areas, but it is also evident among city attorneys and some metropolitan bureaucrats. However, in many of the Eastern cities where the land assembly function of urban redevelopment has produced sites large enough for unified design, pragmatic officials have recognized the need for a new approach to area development.

\section{Breaking Old Regulatory Habits}

The widespread acceptance of the Standard Zoning Enabling Act, ${ }^{2}$ promulgated through the United States Department of Commerce in the 1920's, has provided deep roots everywhere for the conventional lot by lot approach to zoning which Professor Haar has called "Euclidean" - an apt label in view of both its geometrical symmetry and its judicial approbation in Village of Euclid v. Ambler Realty $\mathrm{Co}^{3}$

$\doteqdot$ Former City Solicitor, Pittsburgh, Pennsylvania. Partner, Baskin, Sachs \& Craig, Pittsburgh, Pennsylvania. Affiliate Member, American Institute of Planners. Past President, American Society of Planning Officials.

1 Haar, Emerging Legal Issues in Zoning, 1954 Planning 138 (1955).

2 Standard State Zoning Enabling Act \&1 (U.S. Dep't of Commerce, rev. ed. 1926), reprinted in P. Green, Planning LAW aNd AdmInistration, pt. XII, at 1 (1962) [hereinafter cited as Standard State Zoning ENABLrng Acr]. Widespread acceptance is indicated in BASSETT, ZoNING 29 (1940).

3272 U.S. 365 (1926). 
We have now become so accustomed to the conventional zoning mold that supercautious city attorneys, homeowners' leagues, and also at least one appellate court have reacted negatively to land use controls intended to facilitate flexibility and freedom of design. ${ }^{4}$ Strangely enough, some of the same courts which construe zoning regulations with suspicious strictness on the ground that such rules severely limit private property rights are equally suspicious of flexibility devices like the floating zone which have been introduced to provide greater freedom of private choice. ${ }^{5}$

Doubtless the best way to eliminate the hobbles of conventional zoning is to replace or supplement the standard sort of zoning enabling law with a brand new statute, like the model proposed in this symposium. Until such a model is widely enacted, however, we must consider what potentialities remain in the existing enabling statutes.

\section{The Standard Zoning Enabling Statute}

The power grant section of the standard zoning statute ${ }^{6}$ not only permits the regulation of height and size of structures and the size and percentage of lots required for yards, but also permits regulation of the density of population as such. Thus the statute does not prohibit regulation of density on the straightforward basis of the average number of units for each standard area measure, which is a common attribute of the planned unit development approach. ${ }^{7}$ Similarly, the standard act permits, but does not in terms require, that zones be the chief device by which the location of different kinds of uses are allocated. ${ }^{8}$ Unfortunately, some decisions, such as Rockhill v. Chesterfield Tozenship, ${ }^{\ominus}$ tell us that zoning must involve zones. But even where zones are required, the standard statute does not necessarily bar the adoption of a district tailored for planned unit development, nor does it prohibit unit projects under conditional use procedures within familiar residential district classifications.

Both the location and the internal relationships of a planned unit development involve regulatory methods which need to be examined in the light of the standard zoning statute requirement that zoning regu-

4 See Eves v. Zoning Bd. of Adjustment of Lower Gwynedd Township, $401 \mathrm{~Pa}$. 211, 164 A.2d 7 (1960).

5 Haar \& Hering, The Lower Gwynedd Tozenship Case: Too Flexible Zoning or an Inflexible Judiciary?, 74 HARv. L. REv. 1552 (1961).

${ }^{6}$ Standard State Zoning Enabling Act § 1 .

7 See Chrinko v. South Brunswick Township Planning Bd., 77 N.J. Super. 594, 187 A.2d 221 (Super. Ct. 1963).

8 Standard State Zoning Enabling Act §2.

• 23 N.J. 117, 128 A.2d 473 (1957). 
lations "shall be made in accordance with a comprehensive plan " 10 On the one hand, if a comprehensive plan is evidenced solely by the policy contained in the existing zoning ordinance and by the past actions of the authorities administering the ordinance, ${ }^{11}$ the adoption of provisions which merely authorize new forms and relationships would not necessarily create a conflict. On the other hand, if the comprehensive plan is evidenced, at least in part, by a formal municipal plan, ${ }^{12}$ it is even less likely that planned unit development regulations will be regarded as inconsistent. The general plans for circulation, community facilities, and future land use which constitute most master municipal plans are seldom so detailed or fixed that they would bar a proposal which contains new departures in form and structural relationships. For example, master plan population density goals are almost always stated in terms which are more like the direct density standards of planned unit development than like the round about approach to density achieved by conventional minimum lot size regulations.

The standard statute requirement that "regulations shall be uniform for each class or kind of buildings throughout each district "13 appears broad enough to permit designating planned unit developments as a class significant enough to warrant distinctive treatment, so long as all applicants similarly situated are afforded a like opportunity to meet the required conditions. At precisely this point, however, the cautious city attorney charged with drafting such a conditional use or special exception category finds himself troubled by the fact that every planned unit development has a unique internal design and is therefore different from every other one. He feels satisfied that adequate standards can be drafted to govern the administrative decision as to whether or not a proposed planned unit development can be established at the location in question, but he still entertains concern about the way in which the internal content of the unit development shall be regulated. A rigid set of open space requirements along with bulk and use specifications to govern relationships within the unit would frustrate the development of planned units, but replacing a set of specifications with a plan approval process seems to be a radical departure unless authorization and protection can be found in subdivision control. Therefore any assessment of current statutory

10 Standard State Zoning Enabling Act \$3.

11 For an example see Haar, "In Accordance With a Comprehensive Plan," 68 HARV. L. REV. 1154, 1157 (1955).

12 For an example see Cleaver v. Board of Adjustment of Tredyffrin Township, 414 Pa. 367, 200 A.2d 408 (1964).

13 Standard State Zoning Enabling Act §2. 
powers is incomplete if present day subdivision control statutes are not also evaluated.

\section{Typical Subdivision Control Enabling Statutes}

Written rules which specify bulk and use relationships within a district or conditional use form the basis of conventional zoning practice. Yet any attempt to regulate the internal relationships of a planned unit development solely by previously written rules defeats freedom of design. Planned unit development regulation demands a plan approval process consisting of the subsequent administrative evaluation of a proposed plan in relation to general design standards.

Administrative evaluation is a more plastic method similar to the plan approval procedure of subdivision control which is widely familiar to municipal governments, courts, lawyers, and builders. However, any suggestion that the internal content of planned unit developments can be regulated under the statutory powers of subdivision control is invariably met with the objection that subdivision control can be applicable only where the developer is proposing to divide the title and sell off lots one by one. That objection stems from the customary use of subdivision control, but it overlooks the wording of the standard subdivision control statute.

The Standard City Planning Enabling Act, which has provided the model for many state subdivision control statutes, ${ }^{14}$ defines "subdivision" as follows: "Subdivision' means the division of a . . . parcel of land into two or more . . . sites, or other divisions of land for the purpose, whether immediate or future, of sale or of building development." 15 A literal reading of the statute indicates that regulations need not be limited to situations involving division of title but can be applied when a parcel of land is divided physically by "building development," with or without any intention to divide the title by sale. Thus where other provisions of the subdivision control enabling act of a particular state follow the standard model or are equally broad, a municipality may find that statutory power is already available to implement the plan approval process for the internal control of each planned unit proposal.

\section{The Sinking Zone Approach}

The informal label for an approach which combines the possibilities offered by the present zoning enabling statutes and the sub-

14 See, e.g., Orio Rev. Code Ann. \$711.001 (Page 1954); Wis. Stat. Ann. $\S 236.02$ (8) (Supp. 1965).

15 Standard City Planning Enabling Act $\$ 1$ (U.S. Dep't of Commerce 1928), reprinted in HaAR, LAND-Use Planning $351^{\text {(1959). }}$ 
division enabling statutes is the "sinking zone"-an oversimplified tag which suggests that when a planned unit development location is established, most of the rigid specifications of conventional zoning drop from sight and are replaced by the subdivision control process and its appropriate design standards. ${ }^{10}$

The sinking zone method has been used in four large scale unified design projects undertaken in Pittsburgh. Operating under the existing zoning framework, Pittsburgh has established the classification of RP Planned Residential Unit Development District as a separate zoning district. Establishment of this classification was possible because the pertinent subdivision enabling statute ${ }^{17}$ provides authority to regulate subdivision for "improvement" as well as for sale. The RP District contemplates that every planned residential unit development shall be embodied in an Improvement Subdivision, subject to approval by the city planning commission like all other kinds of subdivisions. The permitted use provision for the RP District reads as follows:

1. Planned Residential Unit Development approved by the commission in accordance with Improvement Subdivision Regulations, and located in an Improvement Subdivision Site Plan approved and recorded pursuant to the Act of May 13, 1927, P.I. 1011, as amended, including:

A. -Dwellings in such combination of types as the commission shall authorize in accordance with the approval of the Improvement Subdivision Site Plan, but the commission shall authorize only those types of dwellings which will (1) form a compatible and harmonious community group or groups, (2) conform to the official master plan of the city, (3) be suited to the capacity of existing and proposed community utilities, facilities and improvements, (4) be capable of a unitary design consistent with the protection of public health, safety and welfare, and (5) afford reasonable protection to the permissible uses of immediately adjacent properties surrounding the site. ${ }^{18}$

A planned unit development is deemed to be a unit of land use which is significant enough to deserve treatment as a separate district. This assumption seems warranted by the fact that the average planned residential development covers more area and is more significant than

${ }_{10}$ The sinking zone must be distinguished from the floating zone which hovers, unlocated, over the zoning map until it is brought down to earth by approval of a rezoning application presented in response to an invitation provided by the zoning ordinance text.

17 Pa. Stat. AnN. tit. 53, §22769 (Supp. 1964).

18 Pittsburgh, $\mathrm{Pa}$, Ordinance 192, $\$ 1311,1958$, as amended, Pittsburgh, $\mathrm{Pa}$., Ordinance 187; 1961. 
the neighborhood shopping complex which is frequently embodied in a separate zone classification. Moreover, the basic question of whether a planned unit development shall be permitted is considered to be so important that it is decided by the elected legislative body rather than by purely administrative action. Thus in the case of Pittsburgh, the city council makes the fundamental decision as to whether or not the proposed unit development location is in accordance with the comprehensive city plan and is appropriate to surrounding land uses and land use zones.

The RP District classification can be readily applied to an area where parcels of land have been newly reassembled by the urban redevelopment process. Such a rezoning process has no attributes more radical than those which exist when a large tract in related ownership is rezoned for ordinary single family development, and conventional subdivision plans are thereafter presented to the planning commission for design approval.

The internal relationships of the planned unit can be reviewed and approved under the subdivision control statute, ${ }^{19}$ which leaves improvement subdivision approval to the planning commission in accordance with the flexible regulations which the planning commission is empowered to adopt under the express terms of the statute. ${ }^{20}$ The fact that the planned residential unit development approvals by the city planning commission of Pittsburgh are not granted on a case by case basis but follow design standards set forth in the regulations establishes a degree of certainty sufficient to insure that all developers will be treated on an equal basis. Final approval of a planned unit is accompanied by a detailed development plan; if division of title is also involved, a compatible parcelization plan is approved and recorded.

\section{Fundamental Problems}

This brief description of the "sinking zone" approach in general, and the Pittsburgh use of subdivision control powers in particular, suggests a series of salient problems which arise each time a jurisdiction tries to make provision for planned unit development, whether under existing statutes or under the new statutory framework now being developed.

1. How many steps should the approval procedure contain? The consensus of municipalities and experienced draftsmen today is

19 Pa. Stat. Ann. tit. 53, \$22769 (Supp. 1964).

20 Performance-type standards for internal design, such as light-access area standards, floor area ratio, and density premiums for open space, illustrate the tendency toward increasing the complexity of concepts to achieve flexibility. Pittsburgh, Pa., Subdivision Regulations, App. A. There is, of course, always the danger that the new "flexible" standards will grow into requirements which are more complicated and more restrictive than the old conventional ones. 
that the approval procedure should contain two basic steps. The first step involves approval of a general plan at a specific location, usually pursuant to a public hearing at which the views of all interested parties may be aired. The second step involves administrative approval of the detailed site plans for the project or for each of its component phases. The two step procedure permits the developer to make changes which inevitably become necessary as plans are translated into reality without the delay and burden entailed in having to present his changes at a public hearing. These two basic steps can be counted as three if the decision as to location alone is treated as a separate initial step, and the count can be extended to four if advisory consideration of a sketch plan is also employed. However, it is believed that the two step procedure achieves the optimum balance between the interests of the developer and of the community. Moreover, the two step procedure has the advantage of familiarity, since it is similar to the widely used, two step subdivision control process, which involves a tentative general plan followed by a final subdivision plan.

2. Which local agency or agencies shall have the power to make decisions at each of the prescribed steps? The choice of which local agencies will conduct each step is closely related to the nature of the steps in the procedure. Whether the legislative body or an administrative agency shall be involved at each step necessarily depends upon the existing statutory framework, on whether or not a redistricting process is involved, and on the desire to categorize each respective step as a policy decision or as an implementing decision. In addition, the responsible municipal officials must, when starting a program of planned unit development controls, consider the personnel available to administer those controls. Obviously the zoning administration personnel who administer the ordinary zoning regulations of a small municipality do not necessarily have the capacity to administer a plan approval process which adds new dimensions to conventional zoning and subdivision control.

A municipal government which lacks adequate personnel within its own ranks has a number of other ways to engage in such a program without sacrificing sovereignty or competency. Capable planning, engineering, and legal skills can be obtained by: (a) a joint administrative program of several neighboring municipalities, perhaps under a regional planning agency; (b) advisory administrative assistance to the municipality's decision making officials by an experienced private consultant; or (c) a contract for similar services with the planning department of the county in which the municipality is located. 
3. Where a general plan is to be developed in successive phases, a feature which is common in large projects, how can adherence to the ultimate overall density goal be assured? Once a general plan has been approved in accordance with an overall population density maximum, component phases-to be developed at different times-may each present differing density results. At least two rules assuring that the approved density maximum will not be exceeded can be formulated:
A. No high density phase may be developed before all low density phases are completed; in other words, as successive phases are developed, the aggregate density actually achieved at any point in time may not exceed the overall density allowed; or
B. Phases may be developed in any order, but regulations and covenants must be devised to restrict all the undeveloped portions in order to assure the municipality that the per- missible average density will not be exceeded.

The unrealistic nature of the first rule and the risks implicit in the second rule are readily apparent. However, in spite of the risk that the restrictions in the second rule may not provide continual assurance of density compliance, it more nearly serves the interests of the community and the developer than the rigidity of the first rule.

4. When the desired open spaces have been achieved, how can permanent maintenance be assured? If the open space in a planned unit development is not fragmented under the control of the individual occupants but is gathered into a common area, the municipal government is very much concerned that permanent maintenance of the open space be assured for the benefit of the general community as well as for the benefit of the project occupants themselves. There are at least four solutions to this problem:

A. The municipality can take over the open space; or

B. The open space can be made the contractual responsibility of the occupants as common interest holders; or

C. A special private entity, such as a cooperative corporation or a homeowners' association can take the responsibility for the open space; or

D. The developer can remain responsible.

Governmental takeover is usually not desired, unless a special park district with assessment powers can be created. Furthermore, if the common open space is not available to the general public, municipal maintenance would be improper. However, even where the general public is served by the open space, the municipality may not be equipped to manage scattered sites. 
Sharing the responsibility in common among the occupants is almost always undesirable because of lack of central leadership and difficulty of enforcement. The management of the open space by a nonprofit corporation or homeowners' association provides the best solution in most cases, except in an all rental project, where the landlord should be required to retain the maintenance obligation.

5. How detailed shall the standards be which govern the location and content of the planned development? Planned unit development controls always involve, to some extent, replacement of continuing written rules by an approved plan which becomes the source of continuing land use control. The temptation to require the recording of a detailed three dimensional site plan should be resisted. It must be remembered that the recording of a very detailed plan and a sale of homes pursuant to that plan will ordinarily confer upon all purchasers the right by way of easement or equitable servitude to require that features shown on the plan be maintained for their mutual benefit, ${ }^{21}$ unless unanimously waived. Thus a municipality which requires a detailed plan to be recorded runs the risk that the developer will be restrained from making any minor site modification however beneficial, or that, if the modification is made, it will become the subject of future litigation. Of course, lawyers recognize that a development scheme need not be recorded in order to confer easement or equitable servitude rights upon those who purchase with reference to it. ${ }^{22}$ However, if a municipality requires only the recording of a parcelization plan, in detail similar to the conventional recorded subdivision plan, the municipal government has at least avoided requiring the creation of common implied servitudes beyond those encountered in prior subdivision practices. The developer's lawyer, moreover, can prevent the unrecorded development scheme from implying unwanted servitudes by means of a note on the recorded parcelization plan, a recorded master covenant agreement, or provisions in the homeowners' association agreement.

In any event, the legal and practical problems involved in formulating modern land use controls can be overcome by an imaginative and resourceful municipality, and they should certainly not be so imposing that they obscure the undeniable advantages which planned unit development offers every community.

21 Morrow v. Highland Grove Traction Co., 219 Pa. 619, 69 Atl. 61 (1908); Sedwick v. Blaney, $177 \mathrm{~Pa}$. Super. 423, 110 A.2d 902 (1955) (dictum) (allocatur denied).

22 Kesselman v. Goldsten, 148 Neb. 452, 27 N.W.2d 692 (1947) ; Rahn v. Hess, 69 Montgomery 433 (C.P. Montgomery Co., Pa. 1953), aff'd, 378 Pa. 264, 106 A.2d 461 (1954). 